\title{
Molecular characterisation and disease severity of leptospirosis in Sri Lanka
}

\author{
Kanchana Kumari Bandara ${ }^{1,2}$, Manjula Weerasekera1/+', Chinthika P Gunasekara1, \\ Nilantha Ranasinghe ${ }^{3}$, Chamil Marasinghe ${ }^{4}$, Neluka Fernando ${ }^{1}$
}

\footnotetext{
${ }^{1}$ Department of Microbiology ${ }^{4}$ Department of Medicine, Faculty of Medical Sciences, University of Sri Jayewardenepura, Sri Lanka ${ }^{2}$ Department of Basic Sciences, Faculty of Allied Health Sciences, General Sir John Kotelawala Defense University, Sri Lanka ${ }^{3}$ Base Hospital, Tangalle, Sri Lanka
}

Leptospirosis is a re-emerging zoonotic disease all over the world, important in tropical and subtropical areas. A majority of leptospirosis infected patients present as subclinical or mild disease while 5-10\% may develop severe infection requiring hospitalisation and critical care. It is possible that several factors, such as the infecting serovar, level of leptospiraemia, host genetic factors and host immune response, may be important in predisposition towards severe disease. Different Leptospira strains circulate in different geographical regions contributing to variable disease severity. Therefore, it is important to investigate the circulating strains at geographical locations during each outbreak for epidemiological studies and to support the clinical management of the patients. In this study immunochromatography, microscopic agglutination test and polymerase chain reaction were used to diagnose leptospirosis. Further restriction fragment length polymorphism and DNA sequencing methods were used to identify the circulating strains in two selected geographical regions of Sri Lanka. Leptospira interrogans, Leptospira borgpetersenii and Leptospira kirschneri strains were identified to be circulating in western and southern provinces. L. interrogans was the predominant species circulating in western and southern provinces in 2013 and its presence was mainly associated with renal failure.

Key words: Leptospira - molecular characterisation - Sri Lanka

Leptospirosis is an endemic, zoonotic disease of public health importance in Sri Lanka (Victoriano et al. 2009). Seasonal outbreaks of leptospirosis occur annually and in 2013, 4,276 cases were reported to the Epidemiological Unit of Sri Lanka. Since Sri Lanka is predominately an agricultural country with a heavy rain fall, exposure to Leptospira is a major occupational hazard (Brenner et al. 1999). Leptospira interrogans, Leptospira santarosai, Leptospira kirschneri, Leptospira borgpetersenii and Leptospira weilli have been reported from several geographical locations in Sri Lanka at different time periods with varying disease severity (Brenner et al. 1999, Agampodi et al. 2012, 2014, Nwafor-Okoli et al. 2012).

Due to the highly endemic nature and associated morbidity and mortality of this disease, it is important to investigate the circulating strains at geographical locations during each outbreak for epidemiological studies and to support the clinical management of the patients.

\section{SUBJECTS, MATERIALS AND METHODS}

This was a prospective hospital based study in western and southern provinces in Sri Lanka between January 2013-January 2014. All the patients more than 18 years of age, presenting with clinically suspected lep-

doi: 10.1590/0074-02760150070

Financial support: World Class University Project (PhD/01/2012),

University of Sri Jayewardenepura

+Corresponding author: mmweera@yahoo.com

Received 18 February 2015

Accepted 19 May 2015 tospirosis according to the World Health Organization (WHO) guideline admitted to the medical wards were included in the study.

Informed consent was obtained from all suspected patients and sociodemographic data and risk factors were gathered using a pre-tested interviewer administered questionnaire. A venous blood sample of $5 \mathrm{~mL}$ was collected following standard procedures and aliquoted into a plain tube for serum separation and the rest added to an ethylenediamine tetraacetic acid (EDTA) tube for DNA extraction. All samples were transported at $4^{\circ} \mathrm{C}$ to the Department of Microbiology, University of Sri Jayewardenepura, Sri Lanka.

IgM immunochromatographic assay and microscopic agglutination test (MAT) - Leptospira infection was presumptively diagnosed by detecting Leptospira specific IgM using a rapid immunochromatographic assay kit (Leptocheck WB; Zephyr Biomedicals, India) following the manufacturer's instructions. MAT was done in order to obtain single MAT antibody titres using the genus specific Leptospira biflexa serovar Patoc 1 strain (Medical Research Institute, Sri Lanka) and $\geq 400$ titre was considered as positive for MAT (WHO 2010).

DNA extraction - EDTA blood samples $(200 \mu \mathrm{L})$ were used for Leptospira DNA extraction using QIAamp DNA blood mini kit (Qiagen GmbH, Germany) according to the manufacturer's instructions. Eluted DNA was quantified and purity was checked using Nanodrop 2000/200C spectrophotometer (Thermo Fisher Scientific, USA).

FlaB polymerase chain reaction (PCR) assay - PCR assay was used to amplify flagella gene present in pathogenic Leptospira species (Kawabata et al. 2001, Natara- 
jaseenivasan et al. 2012). Amplification of isolated DNA was carried out in $50 \mu \mathrm{L}$ volume with $0.5 \mu \mathrm{L}$ template DNA, $5 \mu \mathrm{L} 5 \mathrm{X}$ green GoTaq ${ }^{\circledR}$ Flexi buffer (pH 8.5) (Promega, USA), $2 \mathrm{mM} \mathrm{MgCl}$ (Promega), $0.1 \mu \mathrm{M}$ of each primer (F1-TCTCACCGTTCTCTAAAGTTCAAC, R1CTGAATTCGGTTTCATATTTGCC), $0.4 \mathrm{mM}$ deoxy nucleotide triphosphate (dNTP) mix (Promega) and 0.25 units of Taq DNA polymerase (Promega). L. interrogans DNA was used as a positive control and a negative control without the template DNA were included in each PCR assay. PCR amplification was initiated at $94^{\circ} \mathrm{C}$ for $5 \mathrm{~min}$ followed by 45 cycles of $94^{\circ} \mathrm{C}$ for $1 \mathrm{~min}, 56^{\circ} \mathrm{C}$ for $1 \mathrm{~min}$, $72^{\circ} \mathrm{C}$ for $90 \mathrm{~s}$ and a final elongation step at $72^{\circ} \mathrm{C}$ for $10 \mathrm{~min}$ with final hold at $4^{\circ} \mathrm{C}$. The resulting amplicon was $793 \mathrm{bp}$ and these were stored at $4^{\circ} \mathrm{C}$ until further analysis.

Restriction fragment length polymorphism (RFLP) PCR products of flaB PCR positive patient samples were used for RFLP digestion using Hae III and Hind III restriction enzymes (Kawabata et al. 2001). The restriction digestion was carried out in $20 \mu \mathrm{L}$ of volume in a sterile microcentrifuge tube. The reaction mixture contained 10 $\mu \mathrm{L}$ of PCR product, $2 \mu \mathrm{L}$ of $10 \mathrm{X} \mathrm{RE}$ buffer (Multicore ${ }^{\mathrm{TM}}$ buffer, Promega), $0.5 \mu \mathrm{L}$ restriction enzyme $(10 \mathrm{U} / \mu \mathrm{L})$, $0.2 \mu \mathrm{L}$ of acetylated bovine serum albumin $(10 \mu \mathrm{g} / \mu \mathrm{L})$ and distilled water to a final volume of $20 \mu \mathrm{L}$. The reaction mixture was incubated in an incubator at $37^{\circ} \mathrm{C}$ for 5 $\mathrm{h}$. The final product was subjected to electrophoresis using $2 \%$ agarose gel in tris-acetate-EDTA buffer containing $5 \mu \mathrm{g} / \mathrm{mL}$ ethidium bromide (Sigma Aldrich). Each digested PCR product was mixed with $1 / 5$ volume of the gel loading buffer (Promega) and loaded into the agarose gel. Electrophoresis was carried out at room temperature for one and half hours. At the end of the electrophoresis the gel was visualised under ultraviolet transilluminator (Biometra GmbH, Germany). RFLP was done with three reference serovars: L. interrogans serovar Canicola, Icterohaemorrhagiae and Pyrogenes. An undigested PCR product, where the reaction mix was prepared without Hind 111, Hae 111 restriction enzymes, was used as a control (Figs 1, 2, Lane 2).

Nested PCR - A single tube nested PCR was used to amplify 16S rDNA gene specific for pathogenic and intermediate Leptospira species. Amplification was carried out using PCR primers: rrs-outer F (51-CTCAGAACTAACGCTGGCGGCGCG-31), rrs-outer-R (51GGTTCGTTACTGAGGGTTAAAACCCCC-3'), rrsinner-F (5'-CTGGCGGCGCG T CTTA-3'), rrs-inner-R (5'-GTTTTCACACCTGACTTACA-3') (Boonsilp et al. 2011). PCR master mix consisting of $0.5 \mu \mathrm{L}$ template DNA, $5 \mu \mathrm{L} 5 \mathrm{X}$ green GoTaq ${ }^{\circledR}$ Flexi buffer (pH 8.5) (Promega), $4 \mathrm{mM} \mathrm{MgCl}$ (Promega), 0.2 pmol of each outer primer, 1.2 pmol of inner F, 5 pmol of inner R, $0.2 \mathrm{mM}$ dNTP mix (Promega) and 0.25 units of Taq DNA polymerase (Promega) were used in a total volume of $25 \mu \mathrm{L}$. PCR reaction was carried out using a thermal cycler (Techne Flexigene, UK) with an initial denaturation at $95^{\circ} \mathrm{C}$ for 2 min followed by 40 cycles of $95^{\circ} \mathrm{C}$ for $10 \mathrm{~s}$, $67^{\circ} \mathrm{C}$ for $15 \mathrm{~s}, 72^{\circ} \mathrm{C}$ for $30 \mathrm{~s}$, another 40 cycles of $95^{\circ} \mathrm{C}$ for $10 \mathrm{~s}, 55^{\circ} \mathrm{C}$ for $15 \mathrm{~s}, 72^{\circ} \mathrm{C}$ for $30 \mathrm{~s}$ and a final elongation

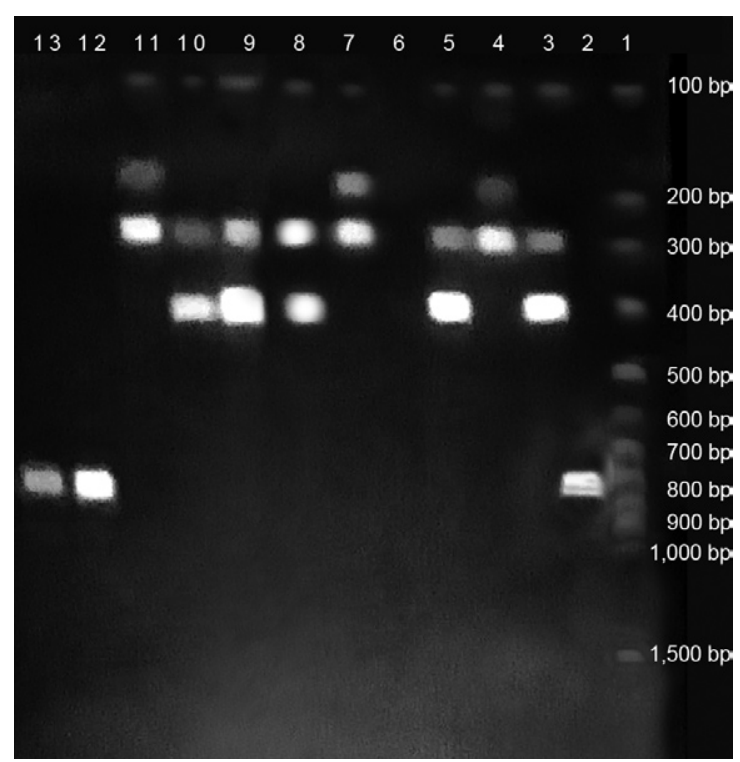

Fig. 1: hae 111 digestion of Leptospira. Lane 1: 100 bp DNA marker; 2: undigested polymerase chain reaction (PCR) product; 3: Leptospira interrogans serovar Canicola (100 bp, $300 \mathrm{bp}, 400 \mathrm{bp}$ ); 4: L. interrogans serovar Icterohaemorrhagiae $(100 \mathrm{bp}, 200 \mathrm{bp}, 300 \mathrm{bp}) ; 5: L$. interrogans serovar Pyrogenes (100 bp, 300 bp, 400 bp); 6; Leptospira biflexa Patoc 1 strain; 7-13: flaB PCR positive patient samples.

step at $72^{\circ} \mathrm{C}$ for $10 \mathrm{~min}$. The resulting amplicon size was a $547 \mathrm{bp}$. Amplicons were visualised by gel electrophoresis using an $1.5 \%$ agarose gel. L. interrogans Serovar Canicola and Leptostpira fainei BUT 6 strain were taken as positive controls and L. biflexa Patoc 1 strain and no template control were used as the negative controls.

PCR products were purified using a PCR product purification kit (Promega) according to manufacturer's protocol and sequenced bidirectionally at Macrogen Inc (South Korea). DNA sequences were obtained using 3.1 Big Dye chemistry. Individual gene sequences were aligned using Bio Edit v.7.0.9.0. Consensus sequences were generated using Chromas v.5.0 and species were identified using National Center for Biotechnology Information (NCBI) BLAST. The gene sequences were deposited in the NCBI GenBank and accessions were obtained. Phylogenetic tree was developed using MEGA 6.0 (Fig. 3).

Ethics - Ethical approval was granted from the Ethical Review Committee of University of Sri Jayewardenepura (application 702/12).

\section{RESULTS}

Out of the 168 leptospirosis suspected patients 153 (91\%) were males while 15 were females. Of these, $43.1 \%$ were farmers, $22.4 \%$ were outdoor laborers, $12.5 \%$ were indoor domestic workers and others included indoor office workers, housewives and school students. The mean age of the study sample was 41 years $( \pm 20)$. The median duration of fever on admission was six days $( \pm 2.5)$. Thirty-nine patients $(23 \%)$ had been treated with antibiotics before admission to the hospital. Leptocheck rapid immunochromatographic assay for Leptospira IgM were 


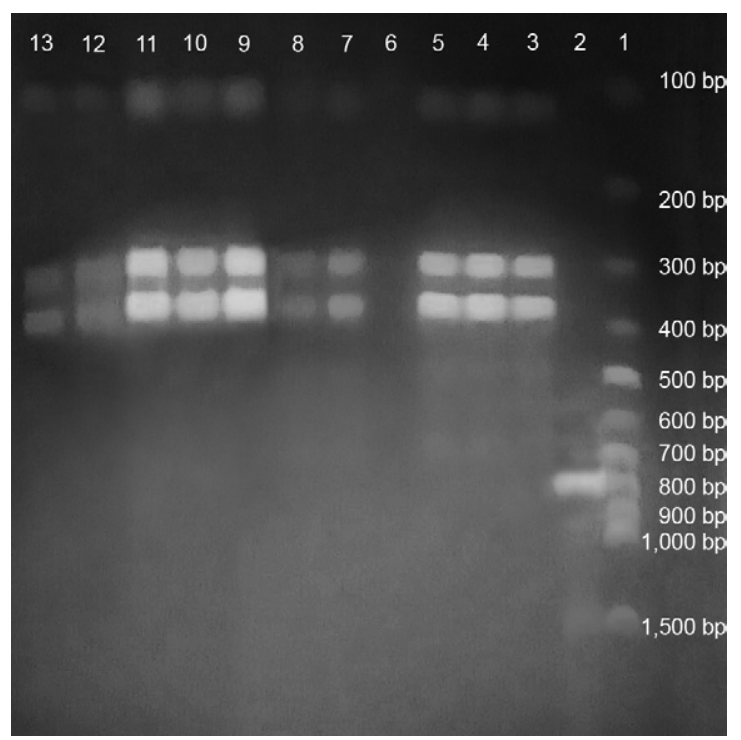

Fig. 2: hind 111 digestion of Leptospira. Lane 1: 100 bp DNA marker; 2: undigested polymerase chain reaction (PCR) product; 3: Leptospira interrogans serovar Canicola; 4: L. interrogans serovar Icterohaemorrhagiae; 5: L. interrogans serovar Pyrogenes; 6: Leptospira biflexa Patoc 1 strain; 7-13: flaB PCR positive patient samples.

\section{TABLE I}

Results of the laboratory diagnosis of leptospirosis based on microscopic agglutination test (MAT) ${ }^{a}$, polymerase chain reaction (PCR) and immunochromatographic assay (Leptocheck) identification methods

\begin{tabular}{|c|c|c|c|}
\hline $\begin{array}{l}\text { Category } \\
\text { (Leptospira case definition) }\end{array}$ & Method & Result & $\begin{array}{l}\text { Patients } \\
\text { n (\%) }\end{array}$ \\
\hline \multirow[t]{5}{*}{ Definitive cases } & MAT & + & $61(36)$ \\
\hline & PCR & + & $14(8.3)$ \\
\hline & MAT and PCR & + & $7(4.2)$ \\
\hline & MAT or PCR & + & $66(39.2)$ \\
\hline & $\begin{array}{l}\text { MAT, PCR and } \\
\text { Leptocheck }\end{array}$ & + & $6(3.6)$ \\
\hline Presumptive cases & Leptocheck & + & $84(50)$ \\
\hline Unconfirmed cases & $\begin{array}{l}\text { MAT, PCR and } \\
\text { Leptocheck }\end{array}$ & - & $73(43.4)$ \\
\hline Total & - & - & $168(100)$ \\
\hline
\end{tabular}

$a$ : single sample MAT $\geq 1: 400 ;$-: negative; +: positive.

positive in $84(50 \%)$ while $13(7.7 \%)$ were positive by flaB PCR. Of the 168 suspected patients, 61 (36\%) had MAT titre of $\geq 1: 400$ (Table I) among them, 90\% had a MAT titre of $\geq 800$.

When the flaB PCR products were subjected to restriction enzyme digestion by Hae III, the DNA of reference strains, L. interrogans serovar Canicola and Pyrogenes (Fig. 1, Lanes 3, 5) resulted in three bands (100 bp, $300 \mathrm{bp}$ and $400 \mathrm{bp}$ ). When the patient samples were tested by digestion with Hae III, three patients (Fig. 1, Lanes 8-10) had a restriction digestion pattern corresponding to L. interrogans serovar Canicola or Pyrogenes. Hae III restriction digestion was not able to differentiate between serovars Canicola and Pyrogenes. The reference DNA from $L$. interrogans serovar Icterohaemorrhagiae (Fig. 1, Lane 4) resulted in 3 bands (100 bp, $200 \mathrm{bp}$ and 300 bp). Two patients in our study had a similar RFLP pattern corresponding to serovar Icterohaemorrhagiae (Fig. 1, Lanes 7, 11). A single band of $700 \mathrm{bp}$ was observed in two patients (Fig. 1, Lanes 12, 13) and they were identified as L. borgpetersenii by DNA sequencing.

Hind 111 digestion resulted in three DNA fragments 100 bp, 300 bp and 350 bp in all reference strains; L. interrogans serovar Canicola, Icterrohaemorrgiae and Pyrogenes. All patient samples tested gave the same banding pattern (Fig. 2). Therefore Hind III was found to be less discriminative in the identification of Leptospira serovars.

Of the 84 Leptospira IgM positive patients, 12 were confirmed as leptospirosis using the nested PCR targeting the 16S rDNA gene. Interestingly, two IgM negative patients also gave positive results by rrs PCR. Therefore, 14 patients had confirmed leptospirosis by rrs PCR.

When risk factors were considered among the 14 leptospirosis confirmed patients, being a farmer $(\mathrm{p}=0.017)$, outdoor laborer $(\mathrm{p}=0.046)$ and contact with contaminated water $(p=0.007)$ showed a significant association with having leptospirosis. All the confirmed leptospirosis patients had an exposure history prior to the onset of the disease. Of these, nine patients reported exposure to contaminated water sources (paddy/agricultural land and flood), five reported animal exposure (cattle, rats and dogs) and three had either cracked heels or wounds on their feet.

Based on sequence analysis, L. interrogans was the most common cause of disease in this study $(\mathrm{n}=11$, $78.57 \%$ ) followed by L. borgpetersenii $(\mathrm{n}=2,14.28 \%)$ and L. kirschneri $(\mathrm{n}=1,7.14 \%)$. The consensus sequences were submitted to GenBank and accessions were obtained as shown in Table II. A BLAST search revealed $99-100 \%$ identity of our isolates to $L$. interrogans, $L$. borgpetersenii and L. kirschneri (Table II).

Phylogenetic analysis shows that $L$. interrogans strains in our study were similar to the Leptospira identified in the 2008 outbreak in the central province of Sri Lanka (Fig. 3). Specimens SLUSJ_1, 2, 16, 111, 160 and 181 in our study were identified as $L$. interrogans which were closely related to isolate 68-JF910147 identified in the 2008 outbreak while specimen SLUSJ_3, 4, 19, 23 and 119 were closely related to L. interrogans isolate 229-JF910145 and isolate 109-JF910144 which were also identified during this outbreak (Agampodi et al. 2011). Specimen SLUSJ_12 and 70 were identified as L. borgpetersenii and specimen SLUSJ_176 was identified as $L$. kirschneri strains (Table II).

When clinical symptoms were analysed almost all patients were febrile on admission and had prostration. Headache (57\%), myalgia (57\%) and muscle tenderness (43\%) were the common symptoms found in all confirmed cases. Conjunctival haemorrhage was seen in $35.7 \%$ of the confirmed leptospirosis patients. Elevated blood urea was seen in $14.2 \%$ whilst serum glutamic oxaloacetic transaminase and serum glutamic pyruvic transaminase were 


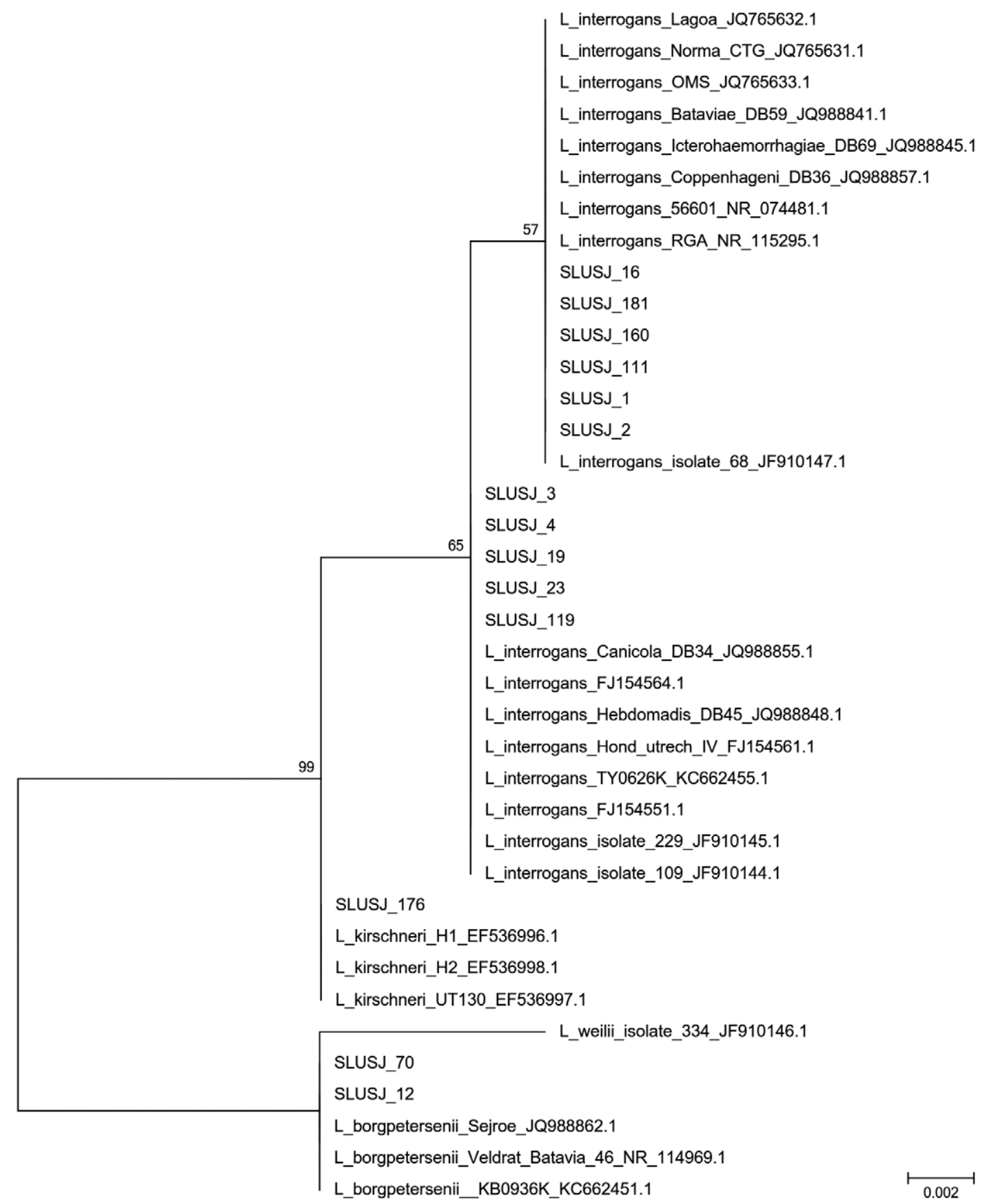

Fig. 3: phylogenic analyses were conducted with MEGA 6.0, the phylogenetic tree being drawn based on 1,000 bootstrap replicates with Kimura 2 -parameter. The numbers on the nodes are the bootstrap support after 1,000 replicates. The specimens identified in the study are denoted by SLUSJ_ $1,2,3,4,12,16,19,23,70,111,119,160,176$ and 181.

raised in $28.5 \%$ patients. Of these patients, $35.7 \%$ had leucocytosis and $57.5 \%$ had neutrophilia whilst haematuria ( $>5$ red blood cells per high power field) was seen in $35.7 \%$. Serum creatinine levels were elevated in $7.14 \%$. Electrocardiography changes were seen in $14.2 \%$. Among the leptospirosis confirmed patients $28.5 \%$ required ICU treatment. Of these patients, $75 \%$ had infection due to $L$. interrogans and $25 \%$ had L. borgpetersenii infection. Renal failure was seen in $35.7 \%$ of the confirmed cases out of them, $80 \%$ were due to $L$. interrogans.

\section{DISCUSSION}

Leptospirosis is a widespread zoonotic infection gaining rapid importance in Sri Lanka due to the fact that the disease is associated with high morbidity and mortality (Agampodi et al. 2011, 2014, Nwafor-Okoli et al. 2012). In this study population, $50 \%$ were presumptively identified as leptospirosis, whilst $36 \%$ were confirmed by MAT (titre $\geq 400$ ) (WHO 2010) (Table I). Of the total suspected patients, 13 were confirmed as leptospirosis by flaB PCR and 14 by rrs PCR, respectively, 
TABLE II

Leptospira sequence identity related to disease complications

\begin{tabular}{|c|c|c|c|c|}
\hline $\begin{array}{l}\text { Specimen number } \\
\text { (SLUSJ_) }\end{array}$ & Identity & $\begin{array}{c}\text { Sequence similarity } \\
(\%)\end{array}$ & GenBank accession & Disease complication \\
\hline 1 & L. interrogans & 100 & KP732501 & Myocarditis \\
\hline 2 & L. interrogans & 100 & KP732502 & Acute renal failure \\
\hline 3 & $\begin{array}{l}\text { L. interrogans strain } \\
\text { Canicola }\end{array}$ & 100 & KP732503 & Acute renal failure \\
\hline 4 & $\begin{array}{l}\text { L. interrogans strain } \\
\text { Canicola }\end{array}$ & 100 & KP732504 & No complications \\
\hline 12 & $\begin{array}{c}\text { L. borgpetersenni strain } \\
\text { sejroe }\end{array}$ & 100 & KP732506 & Liver insufficiency \\
\hline 16 & L. interrogans & 100 & KP732508 & No complications \\
\hline 19 & $\begin{array}{l}\text { L. interrogans strain } \\
\text { Canicola }\end{array}$ & 100 & KP732507 & Liver insufficiency \\
\hline 23 & L. interrogans strain & 100 & KP732509 & Liver failure \\
\hline 70 & L. borgpetersenii strain & 99 & KP732510 & Liver failure \\
\hline 111 & L. interrogans & 99 & KP732511 & Myocarditis \\
\hline 119 & $\begin{array}{l}\text { L. interrogans strain } \\
\text { Canicola }\end{array}$ & 100 & KP732512 & Acute renal failure \\
\hline 160 & L. interrogans & 100 & KP732513 & Acute renal failure \\
\hline 176 & L. kirschneri $\mathrm{H} 2$ & 100 & KР732514 & Acute renal failure \\
\hline 181 & L. interrogans & 99 & KP732515 & No complications \\
\hline
\end{tabular}

TABLE III

Comparison of selected features of leptospirosis outbreaks in Sri Lanka reported in 2008 and 2011 with the current study

\begin{tabular}{lccc}
\hline Feature & $2008^{a}$ & $2011^{b}$ & $2013^{c}$ \\
\hline $\begin{array}{l}\text { Outbreak } \\
\text { Period }\end{array}$ & $\begin{array}{c}\text { Central province } \\
\text { Throughout the year }\end{array}$ & $\begin{array}{c}\text { North central province } \\
\text { Following heavy rains and } \\
\text { floods in first quarter of the year }\end{array}$ & $\begin{array}{c}\text { Western and southern provinces } \\
\text { Throughout the year }\end{array}$ \\
Predominant species & $\begin{array}{c}\text { Leptospira kirschneri } \\
\text { Median duration of fever (IQR) }\end{array}$ & $(26 / 32)$ & L. interrogans \\
Renal failure (\%) & $6(4-8)$ & $6(2-8)$ & $(11 / 14)$ \\
Myocarditis (\%) & 13.8 & 21.9 & $6(4-8)$ \\
\hline
\end{tabular}

a: Agampodi et al. (2011); b: Agampodi et al. (2014); c: current study; IQR: interquartile range.

according to the LERG guideline (WHO 2010). The rapid immunochromatographic assay (Leptocheck) used in this study had a sensitivity of $93 \%$ (Bandara et al. 2014) while the PCR was less sensitive. The high sensitivity of rapid immunochromatographic assay may have been associated with false positives. Similar observations were seen in a study done in India (Panwala et al. 2011). In this study the low PCR positivity may be explained by limited survival of the organism in the collected blood sample, immune system responses, prior use of antibiotics, DNA degradation during transportation and varied level of bacteraemia (Smythe et al. 2002).

RFLP has been used by several researchers to differentiate genotypes of Leptospira (Kawabata et al. 2001, Zakeri et al. 2010). The two restriction enzymes, Hae
III and Hind III, used in our study were unable to differentiate between L. interrogans serovar Canicola and Pyrogenes. However, Hae 111 digestion was more discriminative than Hind 111 digestion for differentiating $L$. interrogans from $L$. borgpetersenii. Thus, its use in Leptospira genotyping is limited which is in line with studies done globally (Kawabata et al. 2001). Therefore, we used a more discriminative $16 \mathrm{~S}$ rDNA sequencing method. Phylogenetic analysis of Leptospira indicates the presence of three clades namely, the pathogenic serovars, nonpathogenic serovars and intermediate group. While the rrs primer is able to identify both pathogenic and intermediate Leptospira species, flaB primers amplify only the pathogenic strains of Leptospira (Agampodi et al. 2011, Boonsilp et al. 2011, Natarajaseenivasan 
et al. 2012). In the current study, SLUSJ_111 gave a positive PCR with rrs, but was negative with the flaB PCR. This can occur as a result of an intermediate strain or due to varying degree of sensitivity of the two assays. In the blast search of the amplified rrs sequence of SLUSJ_111 revealed an identity of $99 \%$ with $L$. interrogans. However, there is still a possibility of this being an intermediate strain because in the current study only a segment of $r r s$ gene was subjected to sequencing. Intermediate species of Leptospira such as Leptospira broomii, Leptospira inadai, Leptospira licerasiae, Leptospira wollfi and $L$. fainei has been reported to cause acute febrile illness (Levett 2001). However there is no documented report of intermediate strains causing leptospirosis in Sri Lanka thus far.

In this study $L$. interrogans strains were the most common cause of disease followed by L. borgpetersenii and L.kirschneri strains. Circulating L. interrogans strains showed a $100 \%$ similarity to the 2008 strain which was isolated from central province in Sri Lanka (Agampodi et al. 2011). The strains isolated in this study showed $100 \%$ similarity to $L$. interrogans which was found to be the predominant strain in the current study and had been reported in Sri Lanka in 2008 outbreak. This strain was identified as a highly virulent strain (Agampodi et al. 2013). Moreover it has been reported from China and the Andaman Islands and seems to be associated with both severe and nonsevere disease (Agampodi et al. 2013).

Among 14 confirmed leptospirosis patients, only 11 developed complications whilst four were managed in intensive care units. Renal failure was the most common $(45 \%)$ complication seen in the current study as seen in 2008 study (Agampodi et al. 2011) (Table III). Further in the current study, L. interrogans was the main cause of renal failure followed by hepatic insufficiency and myocarditis. L. borgpetersenii and L. kirschneri were not detected in the 2008 outbreak, but they have been reported previously during the 1960s and in the recent past from human and animal sources in Sri Lanka (Brenner et al. 1999, Koizumi et al. 2009, Agampodi et al. 2011, 2014). However, circulation of $L$. borgpetersenii among humans has not been well documented previously although it has been found among dairy cattle (Gamage et al. 2014). Cattle may be the source of infection in these two patients.

This study was conducted in the western and southern provinces of Sri Lanka having a different climatic, geographical and socioeconomical conditions when compared to the previous studies done in central and mid central provinces. This study highlights the evolutionary pattern of circulating strains in different time frames in Sri Lanka. In conclusion, L. interrogans was the predominant circulating strain in western and southern provinces in 2013 in Sri Lanka. The current data will contribute to determining molecular epidemiological diversity both in Sri Lanka and globally.

\section{ACKNOWLEDGEMENTS}

To the staff members at the Department of Microbiology, University of Sri Jayewardenepura, to the consultant physicians, to hospital staff members in the respective hospitals in Sri Lanka, to Dr Lilani Karunanayake, Head of Bacteri- ology division of Medical Research Institute, to Ms Rathnamali Perera, for providing diagnostic facility for MAT, and to Dr Menaka Hapugoda, Faculty of Medicine, University of Kelaniya, for providing serological diagnostic kits.

\section{REFERENCES}

Agampodi SB, Dahanayaka NJ, Bandaranayaka AK, Perera M, Priyankara S, Weerawansa P, Matthias MA, Vinetz JM 2014. Regional differences of leptospirosis in Sri Lanka: observations from a flood-associated outbreak in 2011. PLoS Negl Trop Dis 8: e2626.

Agampodi SB, Matthias MA, Moreno AC, Vinetz JM 2012. Utility of quantitative polymerase chain reaction in leptospirosis diagnosis: association of level of leptospiremia and clinical manifestations in Sri Lanka. Clin Infect Dis 54: 1249-1255.

Agampodi SB, Moreno AC, Vinetz JM, Matthias MA 2013. Utility and limitations of direct multi-locus sequence typing on qPCRpositive blood to determine infecting Leptospira strain. Am $J$ Trop Med Hyg 88: 184-185.

Agampodi SB, Peacock SJ, Thevanesam V, Nugegoda DB, Smythe L, Thaipadungpanit J, Craig SB, Burns MA, Dohnt M, Boonsilp S, Senaratne T, Kumara A, Palihawadana P, Perera S, Vinetz JM 2011. Leptospirosis outbreak in Sri Lanka in 2008: lessons for assessing the global burden of disease. Am J Trop Med Hyg 85: 471-478.

Bandara K, Gunasekara C, Weerasekara M, Ranasinghe N, Hapugoda M, Marasinghe C, Perera N, Gunapala A, Dickmadugoda N, Jayalath P, Siwagnanam FG, Fernando N 2014. Evaluation of three commercial rapid immunochromatographic kits for the presumptive identification of leptospirosis in Sri Lanka. Proceedings of the 1st International Conference on Multidisciplinary Approaches, University of Sri Jayewardenepura, August 13-14 2014 Sri Lanka, Faculty of Graduate Studies, University of Sri Jayewardenepura, Sri Lanka, p. 196.

Boonsilp S, Thaipadungpanit J, Amornchai P, Wuthiekanun V, Chierakul W, Limmathurotsakul D, Day NP, Peacock SJ 2011. Molecular detection and speciation of pathogenic Leptospira spp in blood from patients with culture-negative leptospirosis. $B M C$ Infect Dis 11: 338.

Brenner DJ, Kaufmann AF, Sulzer KR, Steigerwalt AG, Rogers FC, Weyant RS 1999. Further determination of DNA relatedness between serogroups and serovars in the family Leptospiraceae with a proposal for Leptospira alexanderi sp. nov. and four new Leptospira genomospecies. Int $J$ Syst Bacteriol 49: 839-858.

Gamage CD, Koizumi N, Perera AK, Muto M, Nwafor-Okoli C, Ranasinghe S, Kularatne SA, Rajapakse RP, Kanda K, Lee RB, Obayashi Y, Ohnishi M, Tamashiro H 2014. Carrier status of leptospirosis among cattle in Sri Lanka: a zoonotic threat to public health. Transbound Emerg Dis 61: 91-96.

Kawabata H, Dancel LA, Villanueva SY, Yanagihara Y, Koizumi N, Watanabe H 2001. flaB-polymerase chain reaction (flaB-PCR) and its restriction fragment length polymorphism (RFLP) analysis are an efficient tool for detection and identification of Leptospira spp. Microbiol Immunol 45: 491-496.

Koizumi N, Muto M, Tanikawa T, Mizutani H, Sohmura Y, Hayashi E, Akao N, Hoshino M, Kawabata H, Watanabe H 2009. Human leptospirosis cases and the prevalence of rats harbouring Leptospira interrogans in urban areas of Tokyo, Japan. J Med Microbiol 58: 1227-1230.

Levett PN 2001. Leptospirosis. Clin Microbiol Rev 14: 296-326.

Natarajaseenivasan K, Raja V, Narayanan R 2012. Rapid diagnosis of leptospirosis in patients with different clinical manifestations by 16S rRNA gene based nested PCR. Saudi J Biol Sci 19: 151-155.

Nwafor-Okoli C, Koizumi N, Kularatne SA, Rajapakse J, Gamage CD, Muto M, Suzuki M, Lee RB, Kanda K, Obayashi Y, Tamashiro H 
2012. Leptospira infection at the University of Peradeniya Teaching Hospital, Sri Lanka: clinical and laboratory investigations. Southeast Asian J Trop Med Public Health 43: 943-950.

Panwala T, Mulla S, Patel P 2011. Seroprevalece of leptospirosis in South Gujarat region by evaluating the two rapid commercial diagnostic kits against the MAT test for detection of antibodies to Leptospira interrogans. National Journal of Community Medicine 2: 64-70.

Smythe LD, Smith IL, Smith GA, Dohnt MF, Symonds ML, Barnett LJ, McKay DB 2002. A quantitative PCR (TaqMan) assay for pathogenic Leptospira spp. BMC Infect Dis 2: 13.
Victoriano AF, Smythe LD, Gloriani-Barzaga N, Cavinta LL, Kasai T, Limpakarnjanarat K, Ong BL, Gongal G, Hall J, Coulombe CA, Yanagihara Y, Yoshida S, Adler B 2009. Leptospirosis in the Asia Pacific Region. BMC Infect Dis 9: 147.

WHO - World Health Organization 2010. Report of the first meeting of the leptospirosis burden epidemiology reference group, WHO, Geneva, 40 pp.

Zakeri S, Sepahian N, Afsharpad M, Esfandiari B, Ziapour P, Djadid ND 2010. Molecular epidemiology of leptospirosis in northern Iran by nested polymerase chain reaction/restriction fragment length polymorphism and sequencing methods. Am J Trop Med Hyg 82: 899-903. 